\title{
Evaluating Women's Labour in 1990s Japan: The Changing Labour Standards Law
}

\author{
Kirsti Rawstron \\ University of Wollongong
}

\begin{abstract}
This article outlines the legislative changes regarding Japanese working women in the 1990s, specifically the changes to the Labour Standards Law. This Law was altered in 1997 (effective 1999) by the removal of a number of provisions known as the Women's 'Protection' Provisions (josei hogo kitei). These gender-specific provisions restricted Japanese women from working particular jobs and hours, and limited overtime and holiday work.
\end{abstract}

The role of these gender-specifc provisions is examined through a collection of articles from four of Japan's mainstream daily, widely-circulated newspapers: the Asahi Shinbun, the Mainichi Shinbun, the Nihon Keizai Shinbun, and the Yomiuri Shinbun. These newspapers were of the opinion that the provisions were simultaneously protective and restrictive towards women. The newspapers all supported the removal of the provisions in order to increase equality in Japan's workforce and society. However, all presented strong concerns that Japanese society was unable to support these changes.

This article situates the law reform within the wider context of 1990s Japan, by tracing the links between labour legislation and socio-cultural issues in Japan, particularly the low fertility rate. This article closes with an evaluation of changes within Japanese society and working habits since the removal of the provisions.

\section{Keywords}

Japan, Gender, Media, Statistics, Labour Standards Law

\section{Introduction}

At the end of the twentieth century, several social issues in Japan began to gain a large amount of media attention - among them, Japan's falling fertility rate and the greying population. ${ }^{1}$ The context for these issues was the gendered division of labour: the large household burden on women and the long working hours for men, as well as the problem

1 The author would like to thank Vera Mackie, Yamaguchi Masataka, and Suzuki Yuko for their generous and valuable support and guidance with this article. 
of so-called 'karōshi' (death from overwork). ${ }^{2}$ Such issues can be seen as symptoms of the same underlying social problem: a lack of gender-based equality. In the 1990s, the Japanese government undertook a range of initiatives in an attempt to address these issues. One of these initiatives was the removal of the Labour Standards Law's Women's 'Protection' Provisions (josei hogo kitei). These gender-specific provisions placed limits on women's hours and places of work, and their removal was hotly debated within the quality mass media. Using the debate around this law reform as a case study, insights can be gained as to how the Japanese media debates gender issues such as equality, difference, and the role of 'protective' legislation.

This article examines the debate in the Japanese mass media over the removal of the gender-specific provisions. By examining items from four mainstream daily newspapers, discourses of both equality and difference are explored and contextualised within Japanese society. I begin with a discussion of the relevant labour legislation, then introduce the debate between the seemingly mutually exclusive logics of equality and difference. This framework is then applied to the Japanese situation. The arguments for and against the removal of the Provisions are addressed in a case study of mainstream newspaper articles, before concluding with recent Japanese labour statistics indicating whether there has been any improvement in gender equality since the provisions were removed.

This work uses newspaper articles to explore gender perceptions in Japan at the close of the twentieth century. ${ }^{3}$ The newspapers in question are four of Japan's largest mainstream daily newspapers: the Asahi Shinbun, the Mainichi Shinbun, the Nihon Keizai Shinbun (commonly known as the Nikkei) and the Yomiuri Shinbun. By using a close case study of their texts, I provide a detailed examination of one example of gender perceptions in Japan. The perceptions within the newspapers reflected public opinion, which in turn influenced legislative change. This article makes a contribution to an exploration of the links between media perceptions of gender, public perceptions and legal change.

\footnotetext{
2 According to the Ministry of Internal Affairs and Communications, women in Japan divided their time almost equally between paid employment and housework. Men, however, spent the majority of their time in paid employment - the average annual hours actually worked was an impressive 1809 hours in 2001, compared to an average of 1715 in the United Kingdom - and less than 15 minutes a day on housework. See Ministry of Internal Affairs and Communications, Statistics Bureau, Historical Statistics of Japan (Tokyo, 2008) and Organisation for Economic Co-Operation and Development, "Dataset: Average annual hours actually worked per worker", OECD Statistics Database for further details.

3 For further references regarding gender perceptions and work in Japan, see, for example, Kawashima, 'Female Workers'; Kimoto, Gender and Japanese Management; Kumamoto-Healey, 'Women in the Japanese Labour Market'; Mackie, 'Equal Opportunity in an Unequal Labour Market'; Ogasawara, Office Ladies and Salaried Men.
} 


\section{Legislation}

There are two Laws which specifically address the intersection of labour and gender in Japan. The first is the Labour Standards Law (Rōdō Kijun Hō, enacted April 1947, effective September 1947) and the second is the Equal Employment Opportunity Law (Danjo Koyō Kikai Kintō Hō, enacted May 1985, effective April 1986). The Labour Standards Law is the foundation of labour law in post-war Japan and legislates both gender equality, and gender difference, through various articles. ${ }^{4}$

The 1947 Labour Standards Law, the 1946 Labour Relations Adjustment Act (Rōdō Kankei Chōsei Hō) and the 1949 Labour Union Act (Rōdō Kumiai Hō) were a trio of labour laws enacted during the Occupation of Japan. ${ }^{5}$ Under the original Labour Standards Law, gender equality is legislated by articles that guarantee equal pay for equal work, regardless of nationality, creed, social status, or gender (Articles 3 and 4). The equality provisions were counterbalanced by a series of articles which relate solely to female employees. Some of the articles address the biological reality of pregnancy - they target expectant or new mothers, and cover maternity, nursing and menstruation leave (Articles 65-7). ${ }^{6}$ With the exception of the articles relating to menstruation leave (which was reclassified in 1986 to become part of the 90 sick days per year allocated to every worker), ${ }^{7}$ the articles which relate to the biological reality of pregnancy have largely been uncontested.

The Articles which have been contested are those which target and affect all working women. These Articles set stricter overtime limits for women than for men (Article 61), prohibit women from engaging in late night work (Article 62), and forbid women from working in 'dangerous' occupations such as mining (Article 63). Commonly known as the josei hogo kitei, which could be translated as Women's 'Protection' Provisions, these provisions have proven controversial - do they protect women from Japan's harsh working conditions, or do they restrict women from achieving their labour potential? The removal of these provisions was the main amendment made to the Labour Standards Law in the late 1990s.

For some occupations, ${ }^{8}$ the provisions were slightly relaxed at the time of the passage of the Equal Employment Opportunity Law in 1986. The Equal Employment Opportunity Law (EEOL) states that employers must endeavour to give both sexes

\footnotetext{
Mackie, ‘Gendered Discourse’, pp. 58-67.

Tanaka, Japanese Legal System, pp. 184-5.

While first called for during Japan's pre-war industrialisation, menstruation leave rose to prominence in the post-war years as a 'quality of life' issue due to the lack of hygienic facilities available to women in most workplaces - see Molony, 'Equality versus Difference', pp. 135-9 for a more detailed explanation.

7 'Yappari Torenai? 'Seirikyūka' 'Shirareru no ga Iya' Nennen Genshōsuru Shinseiritsu (Hard to Take, After all? "Menstrual leave” "Don't Want Anyone to Know About It”: Application Rates are Decreasing Annually)' Yomiuri Shinbun, morning edition, June 7, 1999.

8 Certain occupations, such as nursing, have never been affected by the women's 'protective' provisions.
} 
equal opportunities in recruitment and hiring (Article 7) as well as job assignment and promotion (Article 8). Furthermore, employers were not to discriminate against female employees in terms of education and training (Article 9), benefits (Article 10), or the areas of mandatory retirement age, ${ }^{9}$ retirement, or dismissal (Article 11).

However, the Equal Employment Opportunity Law had some significant drawbacks. This Law made no explicit references to indirect discrimination, was based on a policy of 'equality of opportunity' rather than one of 'equality of result', and was not supported by affirmative action policies, ${ }^{10}$ measures for enforcement, ${ }^{11}$ or punitive measures. ${ }^{12}$ In addition, the EEOL suffered from the circumstances surrounding its inception. The EEOL came about as a direct result of Japan signing and ratifying the United Nation's Convention to Eliminate all forms of Discrimination Against Women (CEDAW). There was strong opposition within Japan from academics and politicians of both sexes who argued that these changes would alter the 'uniquely successful culture' of Japan. ${ }^{13}$ However, there was also support, as women within Japan mobilised both domestic and international networks to place pressure on the government. ${ }^{14}$ The result of this was that the EEOL was not a product of a uniform change in social consensus, but rather an attempt by the Japanese government to make just enough changes to ratify CEDAW and alleviate the combined pressure of the United Nations, domestic supporters, and domestic protesters. ${ }^{15}$

As a reaction to the EEOL, Japanese companies developed a system known as the 'Two-Track Employment System' which in effect is a way of masking gender-based discrimination. New recruits to companies are offered two different employment tracks with very different career paths. One option is sōgōshoku ('integrated' or 'management' track), where the hours are long, the competition fierce, and an expectation of willingness to be transferred if required by the company. All men are directed to this track, and very few women. ${ }^{16}$ Ippanshoku ('general' or 'clerical' track) has shorter hours, limited promotions, and transfers are rare. ${ }^{17}$ Women remain under-represented in the upper echelons of management, medicine and law in Japan. ${ }^{18}$

\footnotetext{
9 Before the passage of the EEOL, 'many companies required women to retire five or more years earlier than male employees, and in many workplaces women customarily took "early retirement" on marriage, pregnancy, or reaching the age of thirty', Mackie, op. cit., p. 60. This had been successfully challenged through several law suits, notably the Sumitomo Cement case, as being unconstitutional, and as such was decreasing as a practice. See Upham, Law and Social Change, pp. 131-132 for further details.

10 Mackie, Feminism in Modern Japan, p. 184.

11 Iwao, The Japanese Woman, p. 178.

2 Nakano, 'Ten Years', p. 65.

3 Upham, Ibid., p. 150.

Mackie, Feminism in Modern Japan, p. 179

Mackie, 'Equal Opportunity in an Unequal Labour Market', pp. 98, 103.

Kawashima, 'Female Workers', p. 286.

7 A discussion of this system is common to most works on Japanese working women. For example, see Kawashima, Ibid., Iwao, The Japanese Woman and Ogasawara, Office Ladies and Salaried Men.

18 See Kimoto, Gender and Japanese Management, for further details.
} 
In the 1990s, realisation dawned within Japan that "simply outlawing direct discrimination and mandating equality of treatment was not sufficient to ensure gender equity and the promotion of individual rights." ${ }^{19}$ As such, the decision was made to revise both labour laws affecting women. Before the Labour Standards Law was revised, Japanese female workers were generally restricted to 150 hours overtime per annum, could not work between 10 p.m. and 5 a.m., ${ }^{20}$ and were unable to work on holidays or in "dangerous" occupations such as mining. Japanese men, on the other hand, had no such limits on night work; they could work 360 hours overtime per annum $^{21}$ (though many worked much longer hours in the guise of 'voluntary' or what is known as 'service' overtime) and there were no limits on the jobs they could do nor the holidays they could work through. In 1990, Japanese workers worked an average of 2,162 hours a year, compared to 1,953 hours in the United Kingdom or 1,948 hours in the United States. ${ }^{22}$

The strong gender distinctions in terms of public and household labour expectations in Japan combined with several other issues at the close of the twentieth century to create an increasingly troubled society. The long working hours of the male population, sometimes leading to karōshi (death from overwork), had combined with an increasing reluctance to marry and many other factors to create a low birth-rate society. The falling birth-rate, when combined with a greying population, has the result of sharply decreasing the future working population while increasing their financial burden. ${ }^{23}$ This is the environment in which the debate surrounding the role of genderspecific protective legislation in Japan is situated.

\section{Labour and Fertility}

The central concern in the debate over the removal of the Provisions was whether the Provisions were protective - or whether they were restrictive. Those who resisted the removal felt that the removal of the Provisions would lead to a form of negative equality - equality of exploitation. ${ }^{24}$ Men's working conditions in Japan are notoriously harsh, and the fear was that if women were freed from the 'protective' provisions, they would be subject to the same exploitative working conditions. Those opposed to the removal argued that if women worked longer hours, they would have less children and less time to devote to their children. As Japan requires more births to counter the ageing population

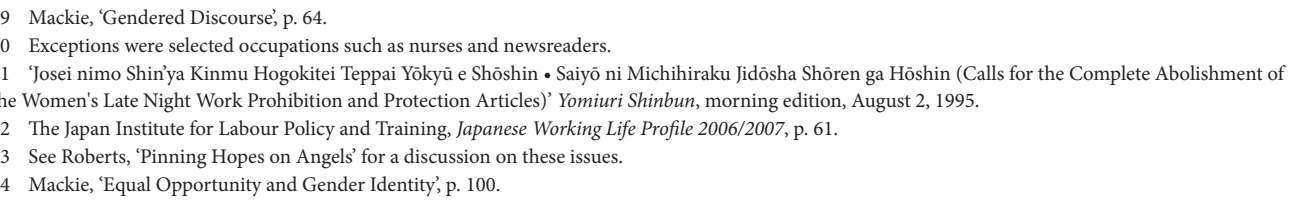


and falling birth-rate, the argument held that women should not work, but rather stay home and raise more children - women should be reproducers, not producers. ${ }^{25}$

This argument has some considerable opposition, however. Frances McCall Rosenbluth has explored low fertility rates from an economic angle and argues that when society creates low barriers to workplace entry and re-entry for women, more children are born. ${ }^{26}$ The higher the opportunity cost of working is for women with children, the less likely women are to undertake motherhood. In Japan, as in many other countries, the expense involved in raising and educating children may act as a disincentive. Living in Japan is expensive, particularly in the major metropolitan cities, ${ }^{27}$ and neither childcare nor education are cheap. ${ }^{28}$ Reacting to worries regarding Japan's future, many young people are unwilling to get married or have children. Young women in particular are dissatisfied "with the burdens placed upon them under the marriage contract, including expectations that they will quit their jobs to raise children and care for the elderly of the family." ${ }^{29}$ Issues such as these have combined with the long life expectancy in Japan to create an ageing, low birth-rate society.

Concerns regarding Japan's low birth-rate gained prominence in the early 1990s when it was revealed that the 1989 total fertility rate was as low as 1.57 births per woman and was continuing to fall. ${ }^{30}$ Over the last half of the twentieth century, marriage ages have increased for both brides and grooms, not only in Japan, but around the world. In Japan, late marriage has a considerable impact on fertility rates, as births outside of wedlock remain rare. ${ }^{31}$ During the 1990 s the Japanese government addressed these concerns through a series of policies, aiming to establish a framework for a more genderequal society which has lower barriers to workplace entry and a more relaxed working environment - a society where men feel able to take childcare leave and spend time with their children and women feel able to raise their children while continuing to work. The Japanese government hoped that by making Japanese society more attractive to women as both mothers and workers that the decreasing workforce would be bolstered and the birth-rate would increase. ${ }^{32}$

\footnotetext{
25 'Rōdōshō Senmonka Kaigi, Koyō Danjo Byōdō e Shishin - Josei no Shokuba Shinshutsu Sokushin e Bosei Hogo Igai Minaoshi (Ministry of Labour Meeting, Discussing Guidelines for Employment Equality - Promoting Women's Workplace Advancement without Reviewing Motherhood 'Protection' Articles)' Nihon Keizai Shinbun, evening edition, May 8, 1982; 'Rōdō Bun’ya no Kisei Kanwa wa Shinchō ni Koyō • Chingin Hakai no Osore Genkōhō Zesei Senketsu (Carefully Relax the Labour Force Controls: Fears of Job and Wage Destruction, Top Priority Correction of Current Law)' Asahi Shinbun, morning edition, January 15, 1996.

26 Rosenbluth, 'The Political Economy of Low Fertility', pp. 3-36.

27 Tokyo and Osaka are ranked as the world's two most expensive cities to live in according to 2009 Data - Mercer, Worldwide Cost of Living Survey 2009 -

City Ranking.

28 Roberts, op. cit., pp. 58-9.

29 Ibid., p. 61.

30 Ibid. The total world replacement fertility rate is 2.335 children per woman; for a developed, East Asian country such as Japan the total replacement

fertility rate is between 2.091 and 2.230. See Espenshade, Guzman and Westoff, 'Global Variation in Replacement Fertility' for further details.

31 Roberts, op. cit., pp. 55-6.

32 Ibid.
} 
However, it is very difficult for a government to stimulate an increase in population. Measures such as banning contraception and abortion or providing awards to particularly fecund women have been used by various states in the past in order to gain a population of sufficient quality and quantity. ${ }^{33}$ Much like measures to increase workplace equality, these efforts can only go so far. Fittingly, since both issues can be seen as symptoms of the same underlying social problem, the Japanese government's approach to both increasing the fertility rate and establishing a more gender-equal workplace involved legislation that was based on voluntary compliance rather than governmental coercion. Knowing that what they were trying to undertake "would require change so basic and far-reaching as to shake society to its very roots... the approach [the Japanese government] adopted was persuasive, educative and meditative in character, based on the twin pillars of voluntarism and gradualism.".34

Among the changes made in the 1990s to encourage a more gender-equal, child-rich society with which to face the new millennium, Japan revised several pieces of existing legislation that addressed the balance between paid work and family life. ${ }^{35}$ As well as widening the scope of prohibited discrimination and introducing what might be called a "name and shame" penalty for employers who violate the discrimination prohibitions under the Equal Employment Opportunity Law, ${ }^{36}$ Japan amended the Labour Standards Law by removing the 'protective' gender-specific provisions. The removal of these 'protective' provisions was addressed at this time in a series of articles from a number of different newspapers around Japan.

\section{Japanese Newspapers}

The Japanese media industry is gargantuan. In 1994, Japan had a population exceeding 120 million with a $90 \%$ literacy rate and 125 daily newspapers which had between them an absolute circulation of nearly 72 million copies per day. ${ }^{37}$ These 125 daily newspapers contain a range of options, opinions and views, though the most widely read and commonly referenced are the Big Five - the Asahi Shinbun, the Mainichi Shinbun, the Nihon Keizai Shinbun (commonly known as the Nikkei), the Sankei Shinbun and the Yomiuri Shinbun - all with massive circulations and supported by widely diversified corporations. ${ }^{38}$ These newspapers are perceived by their readers to maintain specific positions along the political spectrum, though there is little empirical evidence to support this. ${ }^{39}$

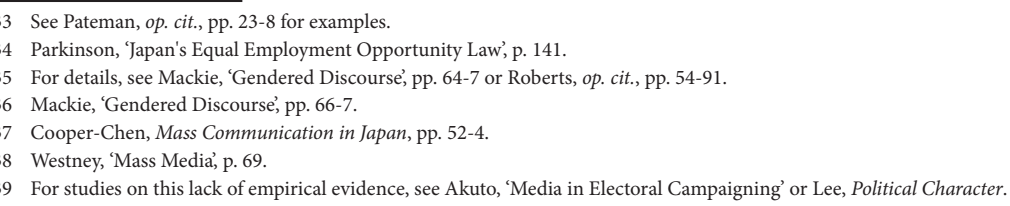


In this study, two newspapers from each side of the political spectrum were chosen to see if gender issues were dealt with differently between perceived 'liberal' and perceived 'conservative' papers. Both of the 'liberal' newspapers, the Asahi Shinbun and the Mainichi Shinbun, were selected, along with the 'conservative' newspaper with the widest circulation, the Yomiuri Shinbun. I chose the Nikkei as the second 'conservative' newspaper over the Sankei Shinbun due to the Nikkei's reputation as "Japan's Wall Street Journal". I was interested in seeing how this gender-related workplace issue was presented to the business community.

While it is common for the term bosei hogo ('protection of motherhood') to include both the provisions that directly relate to mothers and pregnant women and those provisions that apply to all women, ${ }^{40}$ it was the removal of Articles 61 to 63 of the Labour Standards Law that was of particular interest. Thus, this study focused only on those articles containing the phrase josei hogo kitei ('women's protection provisions'). A total of 59 items between the four newspapers was found, ranging in date from May 1982 to July 2005.

My initial hypothesis was that opinions on the law reform would be split along a liberal/conservative line. This, however, was quickly disproved. Rather, all four newspapers called for the same resolution to the debate: that the provisions should be removed, and all warned that workplace gender equality in Japan would not eventuate without significant societal change. All raised concerns regarding Japanese workplace culture and working hours, as well as other gender-related issues such as the falling birth rate. While there was a large degree of consensus between the four newspapers, they had varying focuses and conclusions. The debate surrounding the josei hogo kitei removal was not between the newspapers, per se - there were no articles which stated that a rival paper was incorrect - but rather the debate played out in the papers, with the newspapers supporting various other actors while advancing their own opinions.

\section{Debating the Removal - Equalising Up or Down?}

The debate within the newspaper items was structured along the lines of protection versus restriction. Central to the debate regarding gender-specific legislation are the ideas of 'equality' and 'difference'. Were women different from men and in need of protection from Japan's overwhelming working environment, or were male and female workers essentially equal and the provisions therefore unfair and restrictive? Which should legislation support - should it protect gender difference, or enforce gender equality?

40 Mackie, 'Unequal Labour Market', p. 100. 
The original Labour Standards Law supported difference over equality through the josei hogo kitei. This argument re-emerged in the newspaper debate surrounding the removal of the josei hogo kitei - should the law continue to protect women's difference from men, or should it promote the essential equality between the sexes? The newspapers presented both sides of this argument through quotes from labour and business representatives before making their individual judgements, often using difference arguments and equality arguments interchangeably.

It was business representatives (hereafter referred to as 'management') that called most strongly for the removal of the Provisions. Referred to by the newspapers as keieigawa ('management side'), ${ }^{41}$ keieishagawa ('proprietors' side'), ${ }^{42}$ shiyōsha ('employer') or keieigawaiin ('management committee member'), management used the discourses of equality "to argue that 'equal opportunity' meant 'equal' treatment in all ways." ${ }^{3}$ They failed to situate the long hours of the workplace within the wider social context where Japanese women shoulder the majority of household burdens while Japanese men work some of the longest hours in the developed world. ${ }^{44}$ Management representatives argued for the law to remain as guidelines rather than provisions with punitive measures attached. ${ }^{45}$

Those presented in the media as being on the management side of the debate saw the provisions as restrictive; the provisions not only prevented women from working certain jobs but hindered management's hiring policies by placing legal limitations on a significant sector of the working population. The Nikkei was perhaps the newspaper which presented the most 'management-friendly' side of the debate, often focusing on what the changing law would entail for companies. ${ }^{46}$ Given that the Nikkei is often viewed to be Japan's Wall Street Journal and is aimed at members of the business community, this attitude is relatively self-explanatory.

While management was united in calls for the provisions to be removed, those on the side of workers, the unions, were less supportive of this proposal. A number of different opinions emerged from union discussions, sometimes within a single union. ${ }^{47}$

\footnotetext{
41 'Rōdō bun'ya', Asahi Shinbun, January 15, 1996; 'Koyō Kintōhō Minaoshi “Josei Hogo Kitei” Teppai ga Shōten (EEOL Review: Focal Point: Abolishing the Women's Protection Provisions)' Mainichi Shinbun, morning edition, June 6, 1996; 'Josei nimo', Yomiuri Shinbun, August 2, 1995.

42 'Saiyō • Shōshin, Danjo Sabetsu o Haijo - Kintōhō no Shishin • Shōreian Shimon (Recruitment and Promotion, Eliminate Discrimination - EEOL

Guidelines and Proposed Ordinance)' Nihon Keizai Shinbun, morning edition, November 1, 1985.

43 Mackie, 'Unequal Labour Market', p. 100.

44 Ibid.

45 'Saiyō • Shōshin', Nihon Keizai Shinbun, November 1, 1985.

46 'Saiyō • Shōshin', Nihon Keizai Shinbun, November 1, 1985; 'Keizaishin, Kōdō Keikaku I Hōkoku no Yōshi - Tochi • Jūtaku, Koyō • Rōdō, Iryō • Fukushi (Economic Council, A Summary of the Action Plan Committee Report - Housing and Land, Employment and Labour, Health and Welfare)' Nihon Keizai Shinbun, morning edition, November 27, 1996.

47 'Jidōsha Sōren, Rōkihō no Hogo Kitei Teppai Yōkyū Hataraku Josei no Koe Haikei ni Katsuyaku no Ba Hirogetai (Confederation of Japan Automobile Worker's Unions, Demanding the Abolition of the LSL Protection Articles, Working Women Calling for More Work Opportunities)' Yomiuri Shinbun, morning edition, August 2, 1995.
} 
The trade union movement has been ineffective for Japanese women as even in unions with significant female membership rates, female office-holders were still rare at the time of this debate. The large union federations in Japan have historically centred on full-time workers and unions have been enterprise-based rather than industry-based. ${ }^{48}$ Those in part-time or temporary positions have been dealt with by the newer community and part-timers' unions. Due to the wide range of differences between unions, some unions, such as the Automobile Industry Worker's Union called for the removal of the provisions, citing the need for greater workplace equality ${ }^{49}$ while others, including members of the Aichi Prefectural Federation of Trade Unions, called for the retention of the provisions, declaring that opening women up to harsher working conditions would be detrimental. ${ }^{50}$

The newspaper that provided the most enthusiastic support of the various unions with relation to the josei hogo kitei revisions was the Yomiuri Shinbun. The Yomiuri Shinbun mainly employed the reasoning that without the existence of the josei hogo kitei, women could help prop up Japan's decreasing workforce by creating a larger pool of workers. ${ }^{51}$ The link between high barriers to workplace entry and a low fertility rate was briefly touched on by both the Yomiuri Shinbun ${ }^{52}$ and the Mainichi Shinbun. The Mainichi Shinbun also addressed issues such as the heavy labour burden women face at home, ${ }^{53}$ and called for a more relaxed working environment for both men and women. ${ }^{54}$ The Asahi Shinbun was concerned that if the josei hogo kitei were relaxed, there were no guarantees that discrimination against women would be removed. ${ }^{55}$ In one instance, the Asahi Shinbun stated that the removal of the protection articles at this stage would be putting the cart before the horse by pushing women into positions neither they nor society were prepared for. ${ }^{56}$ However, in spite of concerns regarding death through overwork (karōshi) and Japanese working culture, the Asahi Shinbun did eventually lend its support to the removal of the josei hogo kitei, stating that such a severe dichotomy of roles within Japanese society is no longer acceptable. ${ }^{57}$

The four newspapers surveyed all supported the removal of the provisions but wished for changes in Japanese working culture. In raising concerns over the

\footnotetext{
48 Mackie, Feminism in Modern Japan, p. 132.

49 'Josei Hogo Kitei Teppai o, Jidōshasōren, Teikitaikai de Hōshin - "Shōshin • Shōkaku no Samatageni” (Abolish the Women’s Protective Provisions, Says

Automobile Union's Conference Policy - "Hindrance to Promotions”)' Nihon Keizai Shinbun, morning edition, September 5, 1995.

50 'Kisei Kanwa no Nami, Hataraku Jōken Akka ni Kikikan Kakuchi de Mēdē [Nagoya] (Everywhere on May Day: A Wave of Deregulation, A Feeling of

Crisis Towards the Deterioration of Working Conditions [Nagoya])' Asahi Shinbun, evening edition, May 1, 1997.

51 'Nenkan 1800 Jikan Rōdō o Moru Keizaishi Rōdō Shōi ga Hōkoku (Yearly Working Hours Increased to 1800 Hours: Economics Council Labour

Subcommittee Report)' Yomiuri Shinbun, morning edition, May 21, 1992.

52 "Danshi nomi Boshū" wa Töranai (“Only Men Wanted” is Unacceptable)' Yomiuri Shinbun, morning edition, March 10, 1999.

53 'Koyō Kintōhō Minaoshi', Mainichi Shinbun, June 6, 1996.

54 'Rōdōhō Minaoshi Yutori Shakai o Tōzakeru na (EEOL Review: Don’t Push Away the Expansive Society)' Mainichi Shinbun, September 5, 1998.

55 'Rōdō bun'ya', Asahi Shinbun, January 15, 1996.

56 'Josei Hogo no Haishi wa Yuruyaka ni (Slowly Abolish Women's Protections)' Asahi Shinbun, morning edition, December $20,1996$.

57 'Yuraida "Nibun Hō" Shakai "Danjo" to "Kanmin" ni Miru 96 Nen (Unstable Social "Dichotomy": "Men and Women" and "Government and People"

Examined in 1996)' Asahi Shinbun, December 30, 1996.
} 
hardships that women would face if asked to work the same hours and under the same conditions as men, Japanese newspapers added a new option to the 'equality' versus 'difference' debate. They, like many feminists, called for the protections to be extended to all workers, not just women. ${ }^{58}$ Working on the assumption that gender equality in the Japanese workplace would simply be equality of exploitation, where long working hours for women combined with heavy household burdens would lead to greater social problems, ${ }^{59}$ the newspapers in this study all argued that while the provisions unfairly restricted female workers, the lack of similar protective articles for male workers was equally unfair, and that all workers in Japan needed better protection than currently provided. ${ }^{60}$ To use Susan Atkins' phrase, the newspapers feared that women would be "equalised down" by being forced into the harsh working conditions of men. They opined that all workers in Japan should receive the same protections, which would mean that men would be "equalised up" to a standard of working conditions equal to those afforded women. ${ }^{61}$ As the statistical analysis later in this article shows, the fear of increased exploitation of women in Japanese society has eventuated somewhat; though the total annual hours worked in Japan have dropped since the late 1990s, it does not appear that the sexual division of household labour has equalised. ${ }^{62}$

The situation described by the newspapers is therefore what current feminist thinkers are calling for: an end to the mutually exclusive dichotomy and the creation of legislation that allows workers of both sexes to be different but equal. Though the newspapers considered that the provisions were restrictive towards women, ${ }^{63}$ they felt that unless work-life balance in Japan improved, and issues such as death through overwork (karōshi) were addressed, removing the provisions would be premature. ${ }^{64}$ While the newspapers all reached a consensus on much of the debate, they did have slight differences between them in attitude and focus. Of the four newspapers, I perceived the Asahi Shinbun to be the most reluctant supporter of the removal, with the Yomiuri Shinbun the most enthusiastic. The Mainichi Shinbun often focused on underlying social issues and the Nihon Keizai Shinbun detailed the specifics of the legal changes. All four newspapers expressed hope in Japan eventually establishing a gender-equal society. The remainder of this article uses statistics to analyse if the hoped-for changes in Japanese society have eventuated since the removal of the josei hogo kitei.

\footnotetext{
58 'Josei Hogo no Haishi', Asahi Shinbun, December 20, 1996; 'Shin’ya Rōdō Kisei nado, 'Josei Hogo Kitei’ Teppai o - Rengō ga Jōken Tsuki Yōnin An (Late Night Work Prohibitions, etc, 'Women's Protective Provisions' to be Eliminated - The Unions Accept a Plan with Conditions)' Mainichi Shinbun, morning edition, May 17, 1996; “'Josei wa Ikiiki Hataraiteiru ka” (10) Minaoshi Susumu 'Hogokitei' (Rensai) (“Do Women Work Actively?” (number 10 in series): Progress in Reviewing 'Protective Provisions')' Yomiuri Shinbun, morning edition, July 6, 1996.

59 Mackie, 'Unequal Labour Market', p. 100.

60 While there are legal limitations on men's working conditions, these are often disregarded, particularly those related to overtime limits.

61 Mackie, 'Gendered Discourse', p. 62.

62 Tsuya, Bumpass and Choe, 'Gender, Employment, and Housework in Japan', pp. 207-16.

63 "'Danshi nomi Boshū", Yomiuri Shinbun, March 10, 1999.

64 'Josei Hogo no Haishi', Asahi Shinbun, December 20, 1996.
} 


\section{Labour Conditions in Japan After the Provision Removal}

The newspapers examined in this study hypothesised that when the josei hogo kitei were removed, several changes would occur. Women's labour force participation rates would not only increase, the length of time women would work would increase. ${ }^{65}$ There were also fears that women would become more exploited, working longer hours outside the home while bearing the same burdens within the home. Though the links between labour and fertility rates were only briefly touched upon by the newspapers, there was an expectation that lower work entry barriers for women would lead to a lower opportunity cost of work for women, and therefore to a higher fertility rate. The following statistical analysis shows that many of these predictions have proved correct, though the total changes have been minimal.

It is important to note that, given the difficulties involved in measuring the precise social effects of a legislative change such as the josei hogo kitei removal, much of this analysis is largely speculative in nature. While this article shows what has happened since the provisions were removed, the precise amount of change that can be attributed solely to the removal requires further research beyond the scope of this article.

Each year, the Ministry of Health, Welfare and Labour releases a report entitled "Survey on Working Women". By comparing these reports over the years, a picture develops of the changing situation of working women in Japan. There has been a definite increase in the proportion of women working in almost all age ranges since the removal of the Provisions. Though it cannot be stated that the overall increase in female labour force participation is solely due to the removal of the josei hogo kitei, the available data shows that more women at almost all age levels are partaking in work since the provisions were removed. ${ }^{66}$

65 'Koyō Kintōhō Minaoshi', Mainichi Shinbun, June 6, 1996.

66 It is interesting to note here the shape of the women's employment curve. This M-shaped curve indicates that it is still common for women to leave the workforce in their late 20s, most likely upon marriage or childbirth, before returning to the workplace once their children have grown. For a more detailed discussion of this topic, see Kumamoto-Healey, 'Women in the Japanese Labour Market', pp. 451-3. 


\section{Women's Labour Force Participation Rates}

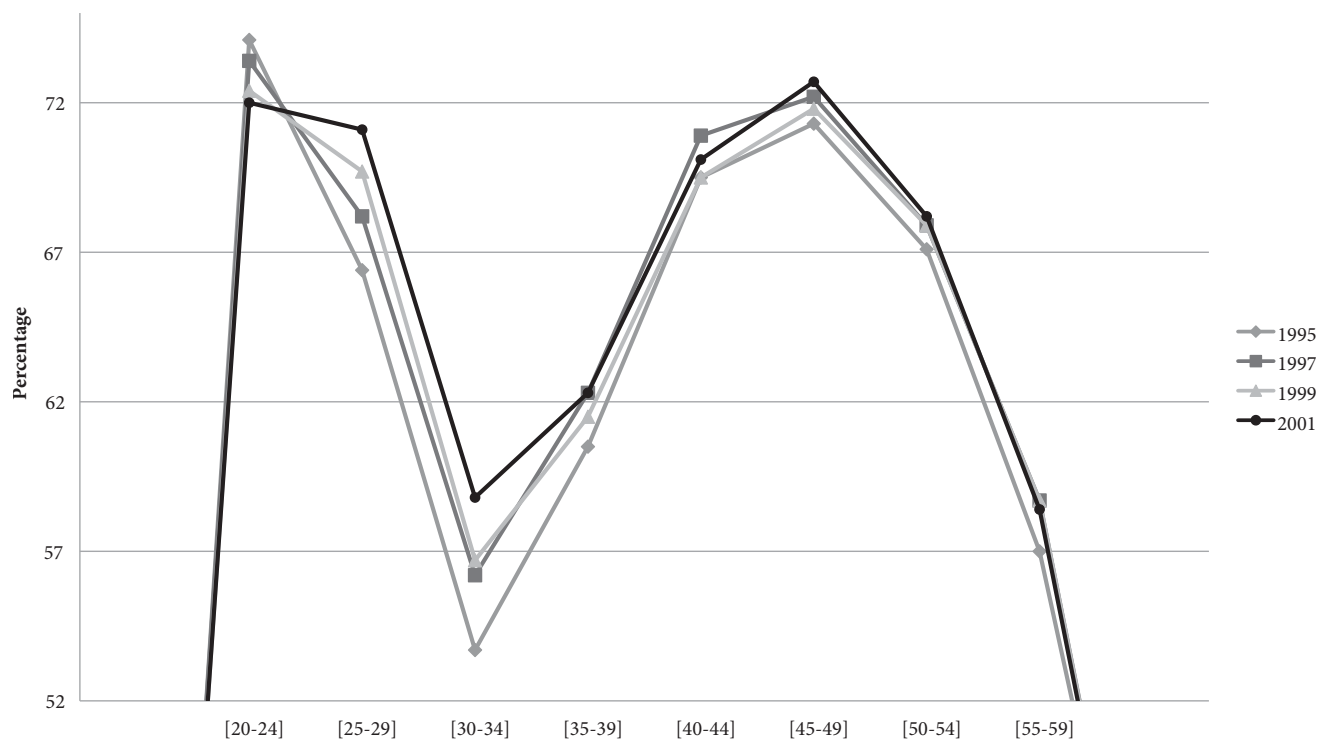

Figure 1 - Sources: International Labour Organisation, LABORSTA Labour Statistics Database, "Table: 1A Total and economically active population, by age group (Thousands)" extracted 3rd June 2010;

Ministry of Health, Labour and Welfare, "Working Women's Situation, 1997", Figure 1-1.

Ministry of Health, Labour and Welfare, "Working Women's Situation, 1999", Figure 1-1.

Ministry of Health, Labour and Welfare, "Working Women's Situation, 2001", Figure 1-1.

While there is a subtle but definite increase in the number of female workers, the inequality of labour force participation rate with male workers remains significant. The percentage of women engaged in work has remained relatively stable in Japan, between $48.5 \%$ of women engaged in work in 1982 to $48.8 \%$ in $2007 .{ }^{67}$ A slight decline in the percentage of women engaged in labour actually occurred between 1997 and 2002 - the period immediately after the removal. This is most likely due to wider economic factors, such as Japan's continuing economic woes and Japan's ageing, declining workforce, though legislative changes, including those discussed here, may have had some effect. In addition to the small total increase in women's labour in Japan, there has been a gradual increase in wage equality, though women's wages remain much lower than their male counterparts. In 1985, women earned $56.02 \%$ of the comparative male wage; by 2005 this had increased to $64.23 \%{ }^{68}$ Wage inequality is slowly decreasing in Japan, though it remains one of the strongest forms of workplace inequality in Japan.

67 Ministry of Internal Affairs and Communications, 2007 Employment Status Survey: Summary of Results, Figure I-2.

68 Ministry of Internal Affairs and Communications, Statistics Bureau, Historical Statistics of Japan, Table 19-36. 
An increase in the number of women working and a slowly equalising level of wage parity are positive indicators of increasing equality within the Japanese workforce. However, the newspapers examined in this study expressed grave concerns over the need for Japan's working culture, in particular working hours, to change so that a better work-life balance could be achieved. To this end, the good news is that annual working hours are steadily decreasing in Japan. Since the late 1990s, annual working hours in Japan have not exceeded those of the United States, which signals a move towards a more work-life balanced society. It is likely that this represents a change in the underlying social assumptions that drive Japan's unhealthy work ethic, as hoped for in the various newspaper items examined in this study.

\section{Annual Hours Worked}

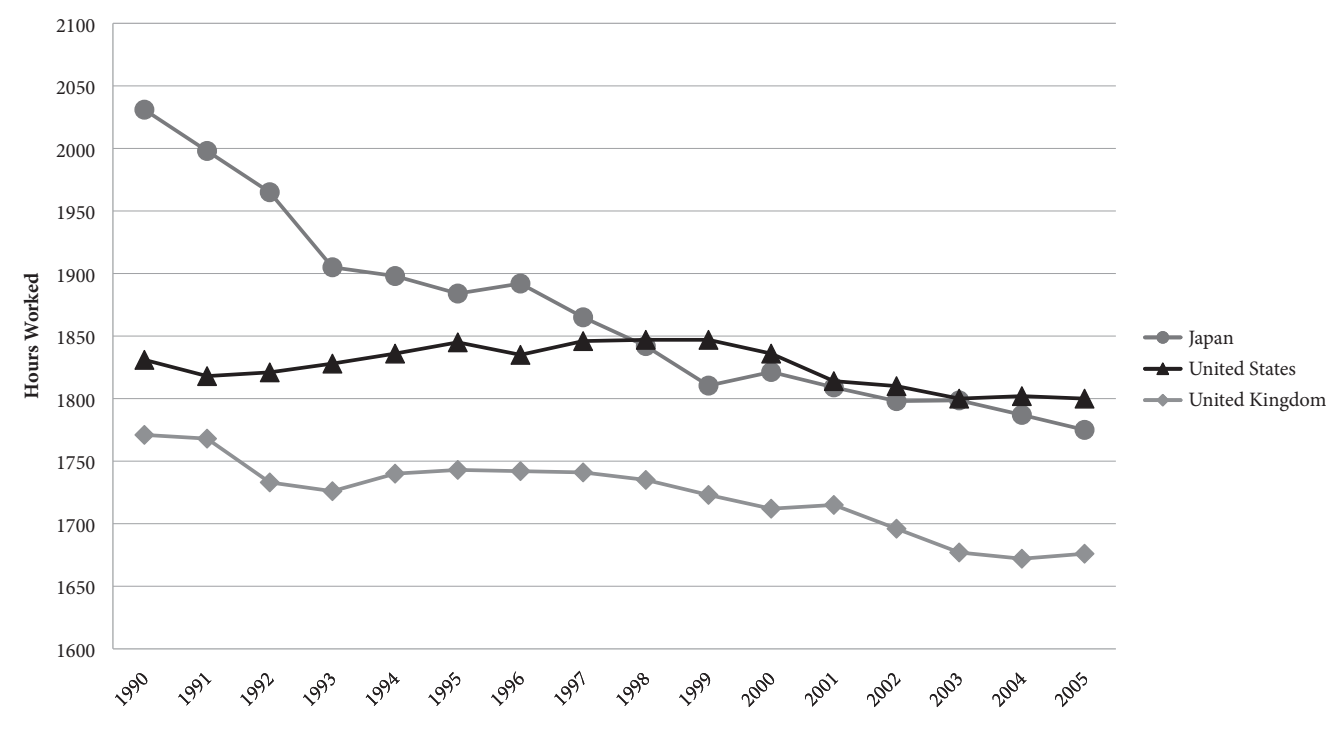

Figure 2 - Source: OECD Statistics Database, "Dataset: Average annual hours actually worked per worker", extracted 4 June 2010.

However, the average number of hours per day that men and women spend on domestic labour remains skewed. While the number of hours a woman spends doing housework each day has decreased from just over 3 hours in 1986 to 2 hours and 42 minutes in 2001, men still spent on average less than 15 minutes a day in domestic labour. This indicates that while support is gaining for women in the workplace, men are proving reluctant to shoulder the burdens of running a household. 
Average Time Spent per Day on Housekeeping (Weekly Average) (1986 - 2001)

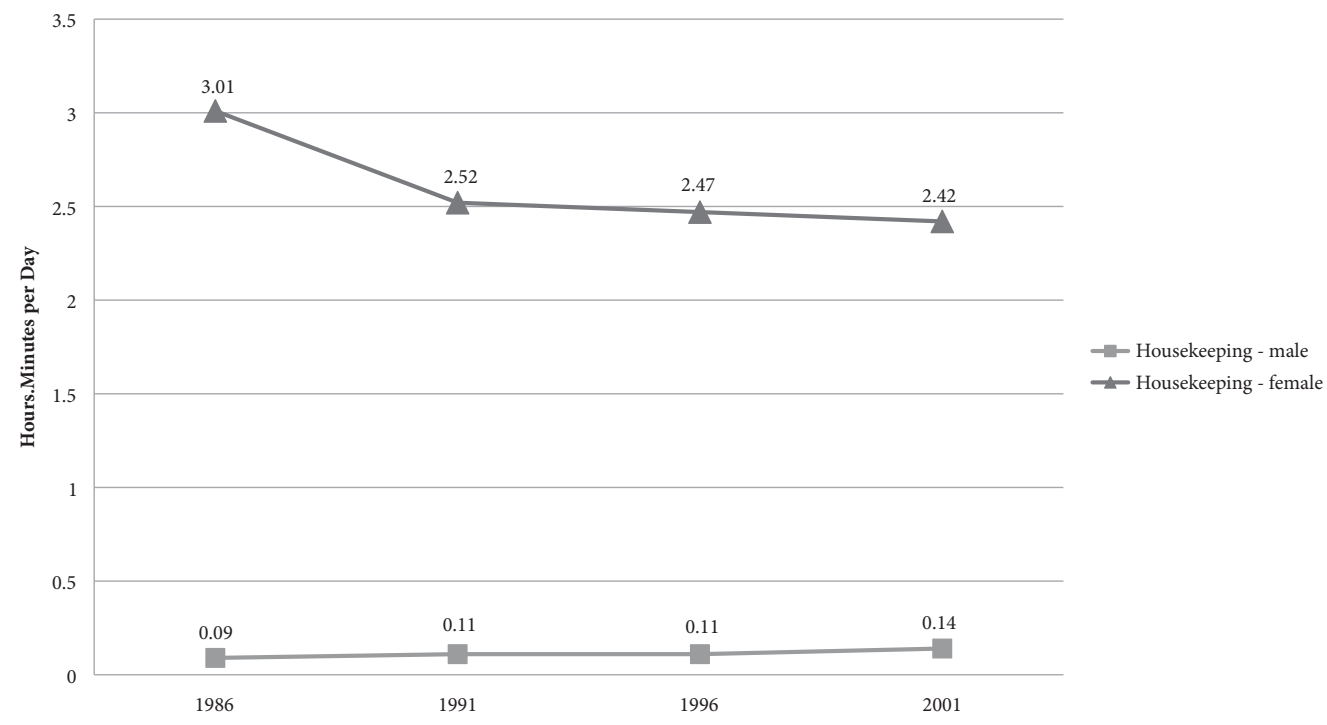

Figure 3 - Source: Ministry of Internal Affairs and Communications, Statistics Bureau, "Historical Statistics of Japan", Table 26-27.

The 1992 Childcare Leave Law established the provisions for childcare leave: workers are allowed to take one year of leave to care for a child, which can be taken by either the mother or the father, or shared between the two. ${ }^{69}$ Though there have been several revisions to this law, ${ }^{70}$ the overwhelming trend remains for mothers to take this leave, rather than fathers - if the mother even continues to work at all. ${ }^{71}$ While some men have begun to take paternity leave, it remains rare. 2010 marked the announcement of the first male local government official in Japan who had decided to take paternity leave (though he stated he planned to remain in the ward in case of emergencies, and would be attending a council meeting during his leave). ${ }^{72}$ While Narisawa Hironobu's decision gained significant exposure in Japan due to its rarity, it is a sign that attitudes in Japan are slowly beginning to turn towards a more gender-equal set of social values, though Narisawa also received some criticism over his decision. ${ }^{73}$

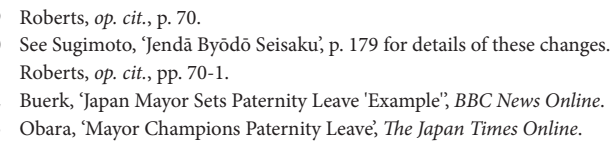


As the above data shows, many of the changes hoped for within the newspaper articles have eventuated. More women are working, and are remaining in work for a longer period of time. ${ }^{74}$ Society is slowly adapting to support a healthier work-life balance, with annual working hours decreasing, though household labour remains heavily divided along gender lines. Though these are positive developments, the newspapers believed that by creating a more balanced society, some of Japan's wider social problems would be addressed, namely the low birth-rate. Unfortunately, as the following graph shows, the fertility rate has not significantly increased since the provisions were removed.

\section{Total Fertility Rate (1950 - 2008)}

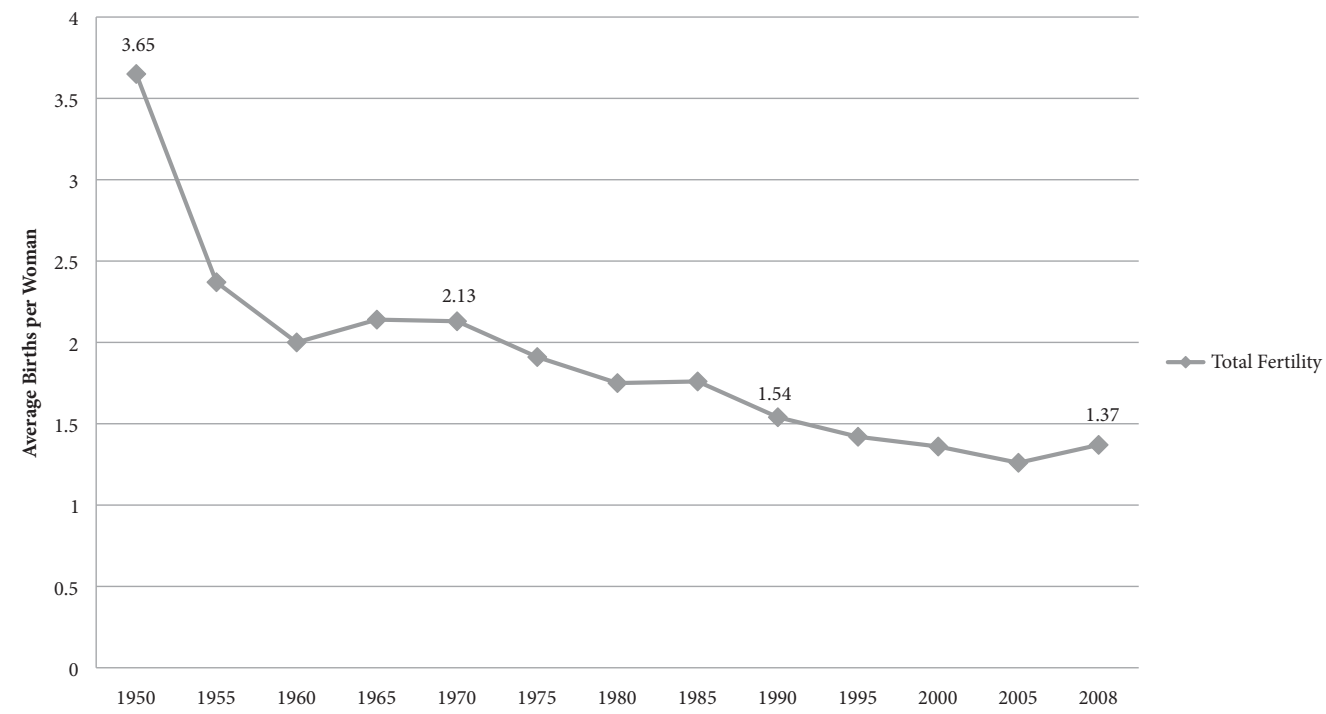

Figure 4 - Source: Ministry of Internal Affairs and Communications, Statistics Bureau, "Statistical Handbook of Japan 2009", Table 2.4.

In addition, the mean age of first marriage, for both brides and grooms, and of mothers bearing their first child are all increasing. The average age of marriage has risen between 1970 and 2008 from 24 years for women and 26 years for men to 28 years and 30 years respectively; the average age that a woman in Japan bears her first child has risen from 25 years in 1970 to 29 years in $2008 .{ }^{75}$ The increasing tendency for women to have their first child later in life places additional pressure on the Japanese fertility rate due to the fact that Japan, unlike many other OECD countries, still "has not shown a trend

74 This study has presented a study of women's labour changes in Japan in the last few decades of the twentieth century. For a further, more detailed examination of the changes to women's lifestyles and working patterns since the end of World War II, see Ueno, The Modern Family in Japan, pp. $41-59$.

75 Ministry of Internal Affairs and Communications, Statistics Bureau, Statistical Handbook of Japan 2009, Tables 2.5 and 2.6. 
towards increases in births outside of marriage." ${ }^{76}$ Government approaches such as the Angel Plan have not yet significantly alleviated this issue. Commentators such as Gotō Jun'ichi have remarked that it is too late to prevent this problem and that population increase measures should have been undertaken as early as the 1950 s. $^{77}$

Although Japan is slowly evolving into a gender-equal society, continuing problems such as these indicate that there is still a strong belief in the difference model of gender within Japanese society. While this was a topic discussed within several of the newspaper articles in this study, further research into the reasons behind the continuance of gender-discrimination in Japan is needed.

\section{Conclusion}

In recent decades, feminists have been torn between two seemingly mutually exclusive concepts: the individualist school of thought that argues that men and women are 'equal' and the relational school that states they are inherently 'different'. This dichotomy has informed most gendered discourses, including those regarding the role of genderspecific legislative provisions. This article has examined this argument within a Japanese context by using newspaper items regarding the removal of the Labour Standards Law's women's 'protection' provisions from four daily mainstream newspapers. The newspapers all supported the removal, stating that the provisions were unfair as men and women are essentially equal. However, they raised concerns that in removing the provisions, women were being equalised down to men's harsh working conditions, and that before gender equality could eventuate in Japan, significant changes needed to be made in Japan's underlying social structure.

By accepting one strand of feminist thought, the concept of the genders being 'equal but different', by creating a more gender equal society and encouraging women to be both mothers and workers, Japan can combat its underlying social problems and reduce such gender-based issues as death from overwork, the low fertility rate, and sex-based discrimination issues in the workplace. While legislation cannot force these changes to occur, actions such as removing the provisions have had a positive effect, with a slight increase in working women and a gradual decrease in annual hours worked indicating that change is slowly occurring in Japan. Whether these gradual changes are quick enough to offset the rapidly greying population and other social issues in twentyfirst century Japan remains to be seen. 
New Voices Volume 4

\section{References}

Akuto, H., 'Media in Electoral Campaigning in Japan and the United States', in Pharr, S. J. and Krauss, E.S. (eds.), Media and Politics in Japan (Honolulu: University of Hawai'i Press, 1996), pp. 313-38.

Buerk, R., 'Japan Mayor Sets Paternity Leave 'Example”, BBC News Online. Retrieved 3 April 2010, from http://news.bbc.co.uk/2/hi/asia-pacific/8601360.stm.

Cooper-Chen, A., Mass Communication in Japan (Ames, Iowa: Iowa State Press, 1997).

“'Danshi nomi Boshū” wa Tōranai (“Only Men Wanted” is Unacceptable)', Yomiuri Shinbun, morning edition, March 10, 1999.

Espenshade, T. J., Guzman, J. C. and Westoff, C. F., 'The Surprising Global Variation in Replacement Fertility', Population Research and Policy Review, vol. 22, no. 5-6 (2003), pp. 575-83.

Gotō, J., 'Aging Society and the Labour Market in Japan: Should the Fertility Rate be Raised Now - No!', Japan Labour Bulletin, vol. 40, no. 9 (2001), pp. 6-11.

International Labour Organisation, "Table: $1 \mathrm{~A}$ Total and economically active population, by age group (Thousands)”, LABORSTA Labour Statistics Database. Retrieved 3 June 2010, from http://laborsta.ilo.org/.

Iwao, S., The Japanese Woman: Traditional Image and Changing Reality (New York: Maxwell Macmillan International, 1993).

Japan Institute for Labour Policy and Training, The, 'Japanese Working Life'. Retrieved 9 May 2010, from http://www.jil.go.jp/english/laborinfo-e/library/JapaneseWorkingLifeProfile2006-2007.pdf.

'Jidōsha Sōren, Rōkihō no Hogo Kitei Teppai Yōkyū Hataraku Josei no Koe Haikei ni Katsuyaku no Ba Hirogetai (Confederation of Japan Automobile Worker's Unions, Demanding the Abolition of the LSL Protection Articles, Working Women Calling for More Work Opportunities)', Yomiuri Shinbun, morning edition, August 2, 1995.

'Josei Hogo Kitei Teppai o, Jidōshasōren, Teikitaikai de Hōshin - "Shōshin • Shōkaku no Samatageni” (Abolish the Women's Protective Provisions, Says Automobile Union's Conference Policy - "Hindrance to Promotions”), Nihon Keizai Shinbun, morning edition, September 5, 1995.

'Josei Hogo no Haishi wa Yuruyaka ni (Slowly Abolish Women's Protections)', Asahi Shinbun, morning edition, December 20, 1996.

'Josei nimo Shin’ya Kinmu Hogokitei Teppai Yōkyū e Shōshin • Saiyō ni Michihiraku Jidōsha Shōren ga Hōshin (Calls for the Complete Abolishment of the Women's Late Night Work Prohibition and Protection Articles)', Yomiuri Shinbun, morning edition, August 2, 1995.

“'Josei wa Ikiiki Hataraiteiru ka” (10) Minaoshi Susumu 'Hogokitei' (Rensai) (“Do Women Work Actively?” (number 10 in series): Progress in Reviewing 'Protective Provisions')', Yomiuri Shinbun, morning edition, July 6, 1996.

Kawashima, Y., 'Female Workers: An Overview of Past and Current Trends', in Fujimura-Fanselow, K. and Kameda, A. (eds.), Japanese Women: New Perspectives on the Past, Present and Future (New York: New Feminist Press at the City University of New York, 1995), pp. 271-93.

'Keizaishin, Kōdō Keikaku I Hōkoku no Yōshi - Tochi • Jūtaku, Koyō • Rōdō, Iryō • Fukushi (Economic Council, A Summary of the Action Plan Committee Report - Housing and Land, Employment and Labour, Health and Welfare)', Nihon Keizai Shinbun, morning edition, November 27, 1996. 
Kimoto, K., Gender and Japanese Management, trans. Castelvetere, T. (Melbourne: Trans Pacific Press, 2005).

'Kisei Kanwa no Nami, Hataraku Jōken Akka ni Kikikan Kakuchi de Mēdē [Nagoya] (Everywhere on May Day: A Wave of Deregulation, A Feeling of Crisis Towards the Deterioration of Working Conditions [Nagoya])', Asahi Shinbun, evening edition, May 1, 1997.

'Koyō Kintōhō Minaoshi “Josei Hogo Kitei” Teppai ga Shōten (EEOL Review: Focal Point: Abolishing the Women's Protection Provisions)', Mainichi Shinbun, morning edition, June 6, 1996.

Kumamoto-Healey, J., 'Women in the Japanese Labour Market, 1947-2003: A Brief Survey', International Labour Review, vol. 144, no. 4 (2005), pp. 451-71.

Lee, J. B., The Political Character of the Japanese Press (Seoul: Seoul University Press, 1985).

Mackie, V., 'Equal Opportunity in an Unequal Labour Market: the Japanese Situation,' Australian Feminist Studies, vol. 9 (1989), pp. 97-110.

-, 'Equal Opportunity and Gender Identity: Feminist Encounters with Modernity and Postmodernity in Japan,' in Sugimoto, Y. and Arnason, J. P. (eds.), Japanese Encounters with Postmodernity (London: Kegan Paul International, 1995), pp. 95-113.

,'Feminism in Modern Japan: Citizenship, Embodiment, and Sexuality (Cambridge: Cambridge University Press, 2003).

-, “The Transformation of the Gendered Discourse of Rights in Postwar Japan', in Scheiber, H. N. and Mayali, L. (eds.), Emerging Concepts of Rights in Japanese Law (Berkeley: Robbins Collection Publications, 2007), pp. 49-71.

Mercer, 'Worldwide Cost of Living Survey 2009 - City Ranking'. Retrieved 9 May 2010, from http://www.mercer.com/costoflivingpr\#top_50.

Ministry of Health, Labour and Welfare, Heisei 9 Nen no Hataraku Josei no Jōkyō (Working Women’s Situation, 1997) (Tokyo, 1998).

, 'Heisei 11 Nen Han Hataraku Josei no Jitsujō (Working Women’s Situation, 1999) (Tokyo, 2000).

, 'Heisei 13 Nen Han Hataraku Josei no Jitsujō (Working Women’s Situation, 2001) (Tokyo, 2002).

Ministry of Internal Affairs and Communications, Statistics Bureau, Employment Status Survey 2007: Summary of Results (Tokyo, 2008).

-----, 'Historical Statistics of Japan (Tokyo, 2008).

,'Statistical Handbook of Japan 2009 (Tokyo, 2010).

Molony, B., 'Equality versus Difference: The Japanese Debate over 'Motherhood Protection', 1915-50', in Hunter, J. (ed.), Japanese Women Working (London, New York: Routledge, 1993), pp. 122-48.

Nakano, M., 'Ten Years Under the Equal Employment Opportunity Law', in AMPO (ed.), Voices from the Japanese Women's Movement (Armonk, New York: M.E. Sharpe, 1996), pp. 65-81.

'Nenkan 1800 Jikan Rōdō o Moru Keizaishi Rōdō Shōi ga Hōkoku (Yearly Working Hours Increased to 1800 Hours: Economics Council Labour Subcommittee Report)', Yomiuri Shinbun, morning edition, May 21, 1992.

Obara, S., 'Mayor Champions Paternity Leave', The Japan Times Online. Retrieved 23 July 2010, from http://search.japantimes.co.jp/cgi-bin/nn20100722f2.html. 
Ogasawara, Y., Office Ladies and Salaried Men: Power, Gender and Work in Japanese Companies (Berkeley, California: University of California Press, 1998).

Organisation for Economic Co-Operation and Development, "Dataset: Average annual hours actually worked per worker”, OECD Statistics Database. Retrieved 4 June 2010, from http://stats.oecd.org.

Parkinson, L., 'Japan's Equal Employment Opportunity Law: An Alternative Approach to Social Change', in Beauchamp, E. R. (ed.), The Japanese Economy and Economic Issues Since 1945 (New York, London: Garland, 1998), pp. 140-98.

Pateman, C., 'Equality, Difference, Subordination: The Politics of Motherhood and Women's Citizenship', in Bock, G. and James, S. (eds.), Beyond Equality and Difference: Citizenship, Feminist Politics and Female Subjectivity (London, New York: Routledge, 1992), pp. 17-31.

'Pāto Shishin Hatarakiyasui Kankyōzukuri Isoge (Part-timers' Guidelines: Hurry Up Making Easier Working Environments)', Mainichi Shinbun, morning edition, February 7, 1999.

Roberts, G. S., 'Pinning Hopes on Angels: Reflections from an Aging Japan's Urban Landscape', in Goodman, R. (ed.), Family and Social Policy in Japan: Anthropological Approaches (Cambridge: Cambridge University Press, 2002), pp. 54-91.

'Rōdō Bun'ya no Kisei Kanwa wa Shinchō ni Koyō • Chingin Hakai no Osore Genkōhō Zesei Senketsu (Carefully Relax the Labour Force Controls: Fears of Job and Wage Destruction, Top Priority Correction of Current Law)', Asahi Shinbun, morning edition, January 15, 1996.

'Rōdōhō Minaoshi Yutori Shakai o Tōzakeru na (EEOL Review: Don’t Push Away the Expansive Society)', Mainichi Shinbun, morning edition, September 5, 1998.

'Rōdōshō Senmonka Kaigi, Koyō Danjo Byōdō e Shishin - Josei no Shokuba Shinshutsu Sokushin e Bosei Hogo Igai Minaoshi (Ministry of Labour Meeting, Discussing Guidelines for Employment Equality - Promoting Women's Workplace Advancement without Reviewing Motherhood 'Protection' Articles)', Nihon Keizai Shinbun, evening edition, May 8, 1982.

Rosenbluth, F. M., 'The Political Economy of Low Fertility', in Rosenbluth, F. M. (ed.), The Political Economy of Low Fertility (Stanford: Stanford University Press, 2007), pp. 3-36.

'Saiyō • Shōshin, Danjo Sabetsu o Haijo - Kintōhō no Shishin • Shōreian Shimon (Recruitment and Promotion, Eliminate Discrimination - EEOL Guidelines and Proposed Ordinance)', Nihon Keizai Shinbun, morning edition, November 1, 1985.

'Shin’ya Rōdō Kisei nado, 'Josei Hogo Kitei’ Teppai o - Rengō ga Jōken Tsuki Yōnin An (Late Night Work Prohibitions, etc, 'Women's Protective Provisions' to be Eliminated - The Unions Accept a Plan with Conditions)', Mainichi Shinbun, morning edition, May 17, 1996.

Sugimoto, K., 'Jendā Byōdō Seisaku no 10nen o Furikaette (Looking Back at 10 years of Gender Equality Policy)', in Ekkyō Suru Jendā Kenkyū (Gender Research Crossing Borders) (Tokyo: Akashi Shoten, 2010).

Tanaka, H. and Smith, M., The Japanese Legal System: Introductory Cases and Materials (Tokyo: University of Tokyo Press, 1976).

Tsuya, N. O., Bumpass, L. L. and Choe, M. K., 'Gender, Employment, and Housework in Japan, South Korea, and the United States', Review of Population and Social Policy, no. 9 (2000), pp. 195-220.

Ueno, C., The Modern Family in Japan: Its Rise and Fall (Melbourne: Trans Pacific Press, 2009). 
Upham, F. K., Law and Social Change in Postwar Japan (Cambridge, Massachusetts: Harvard University Press, 1987).

Westney, E. D., 'Mass Media as Business Organisations', in Pharr, S. J. and Krauss, E. S. (eds.), Media and Politics in Japan (Honolulu: University of Hawai'i Press, 1996), pp. 47-88.

'Yappari Torenai? 'Seirikyūka' 'Shirareru no ga Iya' Nennen Genshōsuru Shinseiritsu (Hard to Take, After all? "Menstrual leave" "Don’t Want Anyone to Know About It": Application Rates are Decreasing Annually)', Yomiuri Shimbun, morning edition, June 7, 1999.

'Yuraida "Nibun Hō" Shakai "Danjo" to "Kanmin" ni Miru 96 Nen (Unstable Social "Dichotomy": "Men and Women" and “Government and People” Examined in 1996)', Asahi Shinbun, morning edition, December 30, 1996. 